\title{
Composition of the editorial boards of leading medical education journals Oktay Tutarel*
}

\author{
Address: Hannover Medical School, Hannover, Germany \\ Email: Oktay Tutarel* - otutarel@hotmail.com \\ * Corresponding author
}

Published: 20 January 2004

BMC Medical Research Methodology 2004, 4:3
Received: 18 September 2003

Accepted: 20 January 2004

This article is available from: http://www.biomedcentral.com/I47|-2288/4/3

(C) 2004 Tutarel; licensee BioMed Central Ltd. This is an Open Access article: verbatim copying and redistribution of this article are permitted in all media for any purpose, provided this notice is preserved along with the article's original URL.

\begin{abstract}
Background: Researchers from the developing world contribute only a limited proportion to the total research output published in leading medical education journals. Some of them believe that there is a substantial editorial bias against their work. To obtain an objective basis for further discussion the present study was designed to assess the composition of the editorial boards of leading medical education journals.
\end{abstract}

Methods: The editorial boards of the three leading medical education journals according to their impact factor were retrieved from the respective January issue of the year 2003. We evaluated in which countries the editorial board members were based and classified these countries using the World Bank income criteria.

Results: Individuals from a number of countries can be found on the editorial boards of the investigated journals, but most of them are based in high-income countries.

Conclusion: The percentage of editorial board members which are based in developing world countries is higher for the leading medical education journals than in most of their psychiatry and general medicine counterparts. But it is still too low.

\section{Background}

A recently published article showed that researchers from the developing world contribute only a limited proportion to the total research output published in leading medical education journals [1]. In addition to less research being done in these countries, other likely reasons for this limited number of publications are poor research methods and problems of presentation such as writing style and language competency $[2,3]$. According to a recent survey researchers from less-developed countries believe that another reason is a substantial editorial bias against their work [3]. As a first step towards examining the objective basis for this claim researchers from the WHO examined the composition of the editorial boards of leading psychiatry journals and found an under-representation of individuals from low-income and middleincome countries [2]. General medical journals follow the same patterns as their psychiatry counterparts [4]. Medical education is one of the most important fields of medicine, because it shapes the future of our profession. Therefore, the discussion how international leading journals in this field really are is of particular importance. As a first step towards obtaining an objective basis for further discussion we recently investigated the geographical distribution of publications in these journals [1]. As a second step the present study was designed to assess the composition of the editorial boards of leading medical education journals. 
Table I: Number of editorial board members per journal and country. The percentage is given in brackets. The countries are separated in groups according to their income level by World Bank criteria.

\begin{tabular}{|c|c|c|c|c|}
\hline & Academic Medicine & Medical Education & Medical Teacher & Total \\
\hline & Total: $15(100)$ & Total: $42(100)$ & Total: $29(100)$ & Total: $86(100)$ \\
\hline $\begin{array}{l}\text { High-income } \\
\text { economies }\end{array}$ & $\begin{array}{l}\text { USA: } 12(80.0) \\
\text { Canada: } 3(20.0)\end{array}$ & $\begin{array}{l}\text { UK: I } 2 \text { (28.6) } \\
\text { Canada: } 7 \text { (I6.7) } \\
\text { USA: } 6 \text { (14.3) } \\
\text { Denmark: } 2(4.8) \\
\text { Hong Kong: } 2(4.8) \\
\text { Netherlands: } 2 \text { (4.8) } \\
\text { Australia: I (2.4) } \\
\text { Austria: I (2.4) } \\
\text { Bahrain: I (2.4) } \\
\text { Ireland: I (2.4) } \\
\text { Italy: I (2.4) } \\
\text { New Zealand: I (2.4) } \\
\text { Spain: I (2.4) } \\
\text { Switzerland: I (2.4) }\end{array}$ & $\begin{array}{l}\text { UK: } 9 \text { (3I.0) } \\
\text { Spain: } 2 \text { (6.9) } \\
\text { Switzerland: } 2 \text { (6.9) } \\
\text { USA: } 2 \text { (6.9) } \\
\text { Australia: I (3.4) } \\
\text { Canada: I (3.4) } \\
\text { Denmark: I (3.4) } \\
\text { France: I (3.4) } \\
\text { Germany: I (3.4) } \\
\text { Israel: I (3.4) } \\
\text { Japan: I (3.4) } \\
\text { Netherlands: I (3.4) } \\
\text { Norway: I (3.4) }\end{array}$ & $\begin{array}{l}\text { UK: } 2 \text { I (24.4) } \\
\text { USA: } 20 \text { (23.3) } \\
\text { Canada: I I (I } 2.8) \\
\text { Denmark: } 3(3.5) \\
\text { Netherlands: } 3 \text { (3.5) } \\
\text { Spain: } 3 \text { (3.5) } \\
\text { Switzerland: } 3 \text { (3.5) } \\
\text { Australia: } 2 \text { (2.3) } \\
\text { Hong Kong: } 2 \text { (2.3) } \\
\text { Austria: I (I.2) } \\
\text { Bahrain: I ( (I.2) } \\
\text { France: I (I.2) } \\
\text { Germany: I (I.2) } \\
\text { Ireland: I (I.2) } \\
\text { Israel: I (I.2) } \\
\text { Italy: I (I.2) } \\
\text { Japan: I (I.2) } \\
\text { New Zealand: I (I.2) } \\
\text { Norway: I (I.2) }\end{array}$ \\
\hline $\begin{array}{l}\text { Upper-middle-income } \\
\text { economies }\end{array}$ & & & $\begin{array}{l}\text { Argentina: I (3.4) } \\
\text { Latvia: I (3.4) } \\
\text { Saudi Arabia: I (3.4) }\end{array}$ & $\begin{array}{l}\text { Argentina: I (I.2) } \\
\text { Latvia: I (I.2) } \\
\text { Saudi Arabia: I (I.2) }\end{array}$ \\
\hline $\begin{array}{l}\text { Lower-middle-income } \\
\text { economies }\end{array}$ & & $\begin{array}{l}\text { Fiji: } 2 \text { (4.8) } \\
\text { South Africa: I (2.4) }\end{array}$ & Romania: I (3.4) & $\begin{array}{l}\text { Fiji: } 2 \text { (2.3) } \\
\text { Romania: I (I.2) } \\
\text { South Africa: I (I.2) }\end{array}$ \\
\hline Low-income economies & & & Bangladesh: I (3.4) & Bangladesh: I (I.2) \\
\hline
\end{tabular}

\section{Methods}

The three leading journals in the subject category "education, scientific disciplines" from the 2001 Journal Citation Reports-Science Edition [5] were selected for this study. These journals are Academic Medicine, Medical Education and Medical Teacher. The editorial board of each journal was retrieved from the January issue of the year 2003. First, we evaluated in which countries the editorial board members are based. Further we classified these countries using the World Bank income criteria [6].

\section{Results}

There are altogether 86 members on the editorial boards of the three journals, with 15 members for Academic Medicine, 42 for Medical Education and 29 for Medical Teacher.

Individuals from 16 different countries can be found on the editorial board of Medical Education, while this number is only two for Academic Medicine and 18 for Medical Teacher. In total 26 countries are represented on the editorial boards of these three journals. Out of the 86 editorial board members $21(24 \%)$ are based in the United Kingdom, while 20 (23\%) are from the USA. The UK is the leading nation on the boards of Medical Education with 12 out of $42(29 \%)$ members and Medical Teacher with 9 out of $29(31 \%)$ members. Individuals from the United States dominate the editorial board of Academic Medicine with 12 out of 15 (80\%) members, while the remaining three are based in Canada. Therefore, only researchers working in North America can be found on the editorial board of this journal. For detailed results refer to Table 1.

While $78(91 \%)$ of the 86 editorial board members are based in countries with a high income according to the World Bank criteria, three (4\%) are based in an uppermiddle-income, four (5\%) in a lower-middle-income and one $(1 \%)$ in a low-income economy. Detailed results for each journal can be found in Table 2.

\section{Discussion}

This study shows that, despite the fact that a number of countries are represented on the editorial boards of the three leading journals in the field of medical education, the majority of the board members are based in only a few countries. Our results are in accordance with the findings of Boldt and Maleck concerning the composition of the editorial boards of major English-language anaesthesia 
Table 2: Classification of the affiliation of editorial board members according to World Bank income criteria

\begin{tabular}{cccccc}
\hline Journal & $\begin{array}{c}\text { Total number of } \\
\text { editorial board } \\
\text { members }\end{array}$ & Low-income economy & $\begin{array}{c}\text { Lower-middle-income } \\
\text { economy }\end{array}$ & $\begin{array}{c}\text { Upper-middle-income } \\
\text { economy }\end{array}$ & $\begin{array}{c}\text { High-income } \\
\text { economy }\end{array}$ \\
\hline Academic Medicine & 15 & 0 & 0 & 0 & 15 \\
Medical Education & 42 & 0 & 3 & 0 & 3 \\
Medical Teacher & 29 & 1 & 1 & 3 & 24 \\
Total & 86 & 1 & 4 & 3 & 78 \\
\hline
\end{tabular}

and critical care journals [7]. They reported that researchers from the United States and the UK together accounted for $62 \%$ of the editorial board members in anaesthesiology journals and for $80 \%$ in critical care journals. In the field of medical education 41 (48\%) out of the 86 editorial board members are living either in the USA or in the UK. But in contrast to our findings that the UK is with a small margin the leading country and that the United States dominates only the editorial board of Academic Medicine, they reported the USA as the leading nation in both categories with $52 \%$ of all editorial board members in anaesthesiology journals and $72 \%$ in critical care journals being based in this country [7]. The dominance of individuals with an affiliation either in the United States or Canada on the board of Academic Medicine resembles the results of a recent study [1], which showed that authors with an affiliation in either of these two countries contributed ca. $95 \%$ of all articles published in this journal between 1995 and 2000 .

Academic Medicine describes itself as "an international forum", Medical Education as "an international, peerreviewed journal"; and Medical Teacher as "an international journal of education in the health sciences". Our search yielded eight board members $(9 \%)$ based in lowincome and middle-income economies out of the total 86 editorial board members. Therefore, leading medical education journals outshine their psychiatry counterparts which have only four board members $(0.8 \%)$ from lowincome and middle-income countries out of the total pool of 530 editorial board members [2]. The results for journals in this field with the exemption of Academic Medicine are also better than those for general medical journals [4]. Horton reported that only eight $(7.2 \%)$ out of 111 editorial board members in five leading general medical journals are based in countries with a medium or low human development index [4]. Three of the five journals had editorial board members only from countries with a high human development index. Despite the fact that the figures for Medical Education and Medical Teacher are better than those reported for most of their psychiatry and general medicine counterparts, they are probably still too low. That Academic Medicine has only board members from the USA or Canada is very unfortunate and does not live up to what one would expect from an "international forum".

But what makes a journal a truly international one? In our opinion, an international journal should have editorial board members from all over the world. In an ideal world not more than fifty percent of the board members should be based in high-income economies. Further Sorrentino and colleagues suggested that it would be wise for journals labelled as international to rotate the editorship among different countries [8]. Truly international journals should publish more papers from foreign countries than from the country of their origin. They should cover the healthcare problems of each part of the world not only those of the developed world. But unfortunately, we do not live in an ideal world. Journals have to be profitable. Therefore, editors and publishers will steer the content of their journals to readers in the developed world, who are more likely to be able to afford subscriptions, and to advertisers who will want to buy space, and organisations that will want to purchase reprints [4]. Further, editors are keen about the impact factor of their journal. Articles that cover diseases encountered more often in the developing world will probably not gather the citations that some editors seek [4].

So, does an editorial bias against the work of researchers from the developing world exist, like some of them believe [3]? The theory that a low proportion of editorial advisers from developing countries is evidence of such a bias remains to be proven [9]. As Greg Wilkinson, the editor of the British Journal of Psychiatry, further pointed out, it remains unclear to what extent, if any, the current location of board members would influence editorial function, for example to implement peer review [9]. And Richard Horton, the editor of The Lancet reminds us, that editorial boards of journals have a variable part to play in decision-making about research papers and editorial policy, with some having little influence [4]. Nevertheless, the lack of representation of the developing world on editorial boards should be a matter of concern to all of us, because editorial boards can help to shape the personali- 
ties and policies of a journal and their composition sends a signal to authors and readers about a journal's interest [4]. Unfortunately we have to recognize that the present make-up of editorial boards in the different fields of medicine probably does not send an encouraging signal to researchers in the developing world.

\section{Conclusions}

Individuals from a number of countries can be found on the editorial boards of the leading medical education journals, but the majority of them are based in only a few countries.

Despite of each journal describing itself as international, most of the editorial board members are based in highincome countries according to the World Bank income criteria.

\section{Competing interests}

None declared.

\section{Authors' contributions}

OT designed and carried out the study. He performed the analysis and interpretation of the data and wrote the manuscript.

\section{References}

I. Tutarel O: Geographical distribution of publications in the field of medical education. BMC Med Educ 2002, 2:3.

2. Saxena S, Levav I, Maulik P, Saraceno B: How international are the editorial boards of leading psychiatry journals? Lancet 2003, 36I:609.

3. Horton R: North and South: bridging the information gap. Lancet 2000, 355:2231-2236.

4. Horton R: Medical journals: evidence of bias against the diseases of poverty. Lancet 2003, 36 I:712-713.

5. Thomson-ISI: 200 I Journal Citation Reports on microfiche - Science Edition Philadelphia; 2002.

6. World Bank Group - Data and Statistics. Country Groups [http://www.worldbank.org/data/countryclass/classgroups.htm]

7. Boldt J, Maleck W: Composition of the editorial/advisory boards of major English-language anesthesia/critical care journals. Acta Anaesthesiol Scand 2000, 44: I75-I79.

8. Sorrentino D, De Biase F, Trevisi A, Bartoli E: Scientific publications in gastroenterology and hepatology in Western Europe, USA and Japan in the years 1992-1996: a global survey. Digestion 2000, 61 1:77-83.

9. Wilkinson G: How international are the editorial boards of leading psychiatry journals? Lancet 2003, 36 I: I 229.

\section{Pre-publication history}

The pre-publication history for this paper can be accessed here:

http://www.biomedcentral.com/1471-2288/4/3/prepub
Publish with Biomed Central and every scientist can read your work free of charge

"BioMed Central will be the most significant development for disseminating the results of biomedical research in our lifetime. "

Sir Paul Nurse, Cancer Research UK

Your research papers will be:

- available free of charge to the entire biomedical community

- peer reviewed and published immediately upon acceptance

- cited in PubMed and archived on PubMed Central

- yours - you keep the copyright

Submit your manuscript here:

http://www.biomedcentral.com/info/publishing_adv.asp
BioMedcentral 